\title{
A COPROLOGICAL SURVEY OF PARASITES OF SEVEN MAMMAL GROUPS AT SILENT VALLEY NATIONAL PARK, KERALA
}

\author{
Francis Xavier', Gigi K Joseph ${ }^{2}$, Bindhu Michael ${ }^{1}$ and K. Bijula ${ }^{1}$ \\ ' Livestock Research Station, Thiruvazhamkunnu, Palakkad, Kerala, India. \\ ${ }^{2}$ Kerala Forest Research Institute, Peechi, Thrissur, Kerala, India.
}

\begin{abstract}
During an ecological study in Silent Valley National Park, fecal samples of seven mammalian taxa were collected and analysed for parasites. The analysis revealed that Lion-tailed Macaques, Nilgiri Langur, Leopard, Porcupine, Small Indian Civet and Toddy Cat were hosts to nematodes, except Sloth Bear. Cestode infestation was recorded from Porcupine and Small Indian Civet and trematodes were found in the feces of Leopard and Toddy Cat.

Introduction

Silent Valley National Park is a rectangular table land in the southwestern corner of Nilgiris and is considered one of the most valuable gene reserves of the country. This 8,952 ha. pristine forest of Kerala State lies between the latitudes of $10^{\circ} 15^{\circ}$ and $11^{\circ} 25^{\prime} \mathrm{N}$ and the longitudes $76^{\circ} 21^{\prime}$ and $76^{\circ} 33^{\prime} \mathrm{E}$. The height varies from 658 to $2383 \mathrm{~m}$. The average ambient temperature is $23.8^{\circ} \mathrm{C}$ and a rainfall above $3000 \mathrm{~mm}$. Out of the 60 species of mammalian fauna in the forests of Kerala, around 40 species are among the better known large and medium sized ones (Balakrishnan \& Xavier, 1995). The ecological insulation of this National Park provides abode to many a number of mammals that have become extinct elsewhere.
\end{abstract}

In conjunction with an ecological study in the Silent Valley National Park, fecal samples were collected from the Lion-tailed Macaque (Macaca silenus), Nilgiri Langur (Trachypithecus johnii), Sloth Bear (Melursus ursinus), Leopard (Panthera pardus), the Indian Porcupine (Hystrix indica), the Small Indian Civet (Viverricula indica), and the Common Palm Civet or Toddy Cat (Paradoxurus hermaphroditus) for a parasitological investigation.

\section{Materials and Methods}

As part of an ecological survey conducted in the Silent Valley National Park, between June 1994 and December 1994, forty five fresh fecal samples were collected along tracks, roads, trails and river sides. It was identified to be of seven different mammal

Received on 10 November 1999

Accepted on 6 April 2000 groups. When defecation was not directly observed, samples were differentiated by their size, animal presence and presence of scraps associated with them (Rabinowitz \& Walker, 1991). Samples preserved in $10 \%$ formalin, were examined for parasite eggs, larvae, cysts, and oocysts by centrifugal salt floatation and sedimentation techniques.

\section{Results and Discussion}

Analysis of the samples indicated that parasitism was highly prevalent among many of the mammal groups in this National Park. Forty two of the 45 samples were found to be positive for parasitism. The prevalance of various species of parasites and the probable identity of those parasites are presented in Table 1. Of the 45 samples examined 58 per cent were found positive for parasites.

All Lion-tailed Macaque fecal samples collected were infected with nematodes of Trichuris species and Oesophagostomum species. Presence of Trichuris species was more when compared to the Oesophagostomum species. The presence of the two nematode parasites may be related to the feeding habit of the Lion-tailed Macaques. They are arboreal and infected animals can contaminate all feeding material in the process of their defecation from the tree tops, as it gets scattered. The ingestion of food, contaminated with eggs of the parasite and their third stage larvae causes infection (Soubsby, 1982). The same parasites were identified in the fecal samples of Nilgiri Langur which also eats fruits, flowers, leaves, shoots and buds (Balakrishnan \& Xavier, 1995).

Nematodes of Ancylostoma species and trematodes of Paragonimus species were identified from fecal samples of Leopards. These parasites have been commonly reported from wild felids (Patton et al., 1994). Ancylostomes are reported to infect a host through different ways viz. oral, dermal, transcolostural and prenatal routes (Soulsby, 1982; Georgi \& Georgi, 1990). The carnivorus feeding habit of Leopards make them susceptible to these parasites.

Porcupines which feed on roots, fruits, and bark are very common in the forests. Nematodes of Trichuris species and Ascaris 
Table 1. Parasitic incidence in seven mammal groups of Silent Valley National Park.

\begin{tabular}{|c|c|c|c|c|c|c|c|c|c|}
\hline Animal & $\begin{array}{l}\text { Scientific } \\
\text { Name }\end{array}$ & $\begin{array}{l}\text { Sample } \\
\text { Size }\end{array}$ & $\begin{array}{l}\text { No. } \\
\text { infested }\end{array}$ & Nematodes & $\%$ & Cestodes & $\%$ & Trematodes & $\%$ \\
\hline $\begin{array}{l}\text { Lion-tailed } \\
\text { Macaque }\end{array}$ & Macaca silenus & 3 & 3 & $\begin{array}{l}\text { Trichuris sp. } \\
\text { Oesophagostomum }\end{array}$ & $\begin{array}{l}66.67 \\
33.33\end{array}$ & - & - & - & - \\
\hline Nilgiri Langur & $\begin{array}{l}\text { Trachypithecus } \\
\text { johni }\end{array}$ & 11 & 8 & $\begin{array}{l}\text { Trichuris sp. } \\
\text { Oesophagostomum }\end{array}$ & $\begin{array}{l}87.5 \\
75\end{array}$ & - & - & - & - \\
\hline Sloth Bear & Melursus ursinus & 2 & 0 & - & - & - & - & - & - \\
\hline Leopard & Panthera pardus & 4 & 3 & Ancylostoma sp. & 100 & - & - & Paragonimus sp. & 100 \\
\hline Porcupine & Hystrix indica & 5 & 4 & $\begin{array}{l}\text { Trichuris sp. } \\
\text { Ascaris sp. }\end{array}$ & $\begin{array}{l}50 \\
50\end{array}$ & Hymenolepsp. & 25 & - & - \\
\hline $\begin{array}{l}\text { Small Indian } \\
\text { Civet }\end{array}$ & Viverricula indica & 8 & 3 & Ascaris sp. & 66.67 & Diphylobothrium sp. & 33.33 & - & - \\
\hline Toddy Cat & $\begin{array}{l}\text { Paradoxurus } \\
\text { hemaphroditus }\end{array}$ & 12 & 5 & Ancylostoma sp. & 100 & - & - & Paragonimus sp. & 20 \\
\hline
\end{tabular}

species were identified in the fecal samples collected in the present survey. One sample was positive for Ancylostoma ova. Cestodes of Hymenolepis species were also identified in one sample.

Among the smaller mammals, Small Indian Civet scat samples contained nematode parasites of Ascaris species and cestode parasites of Diphylobothrium species. The samples from Toddy Cats had nematodes of Ancylostoma species and trematodes of Paragonimus species. The Sloth Bear was the only animal in which no parasites could be identified. Low sample size may be a reason for the absence of parasite ova in this animal.

\section{Acknowledgement}

The authors thank Dr. K. Madhavan Pillai, Professor and Head, Department of Parasitology, College of Veterinary and Animal Science, Mannuthy, for the help in the present survey.

\section{References}

Balakrishnan, M and F. Xavier (1995). Animal resources of Kerala. Prospects of resources utilization and employment opportunities. Invited paper. Science and Technology for Development. Govt. of Kerala, $54 \mathrm{pp}$.

Georgi, J.R. and M.E. Georgi (1990). Parasitology for Veternarians. 5th ed. W.B. Saunders and Company, Philadelphia.

Patton, S., A. Rabinowitz, S. Randolph and S.S. Johnson (1994). A coprological survey of parasites of wild neotropical felidae. $J$. Wildlife Diseases 30(3): 474-517

Rabinowitz, A. and S.R. Walker (1991). The carnivore community in a dry tropical forest mosaic in Huai Khaeng Wildlife Sanctuary. $J$. Trop. Eco. 7: 37-47.

Soulsby, E.J.L. (1982). Helminths Arthropodes and Protozoa of Domestic animals. Lea and Febiger, Philadelphia. 808-815. 